\title{
FIOS DE O FIO DA MEMÓRIA
}

\author{
Jaime Rodrigues \\ Doutorando em História no IFCH/UNICAMP e Bolsista FAPESP
}

RESUMO: Este artigo discute o filme $O$ fio da memória. A partir das memórias do protagonista, Gabriel, são articuladas ligações entre temas e personagens. Um deles é a experiência negra em perspectiva histórica, ressaltando aspectos como religiosidade e música na formação da identidade.

PALAVRAS CHAVE: Cinema brasileiro - Memória popular - Identidade negra - Brasil (século XX).

ABSTRACT: This articles discusses Eduardo Coutinho's movie Memory thread. From its protagonist (Gabriel) memory, it links subjects and characters. One of them is black experience in historic perspective, emphasizing points of view as religiousness and music in identity formation.

KEYWORDS: Brazilian cinema - Popular memory - Black identity - Brazil (XX. century).

Eduardo Coutinho inicia e encerra seu filme $O$ fio da memória com cenas do mar batendo nas pedras. Isso pode ser interpretado como uma metáfora em relação à memória: o mar se movimenta num eterno ir e vir, tal como a memória, especialmente da forma como ela é representada nesse documentário. O filme não segue - e tampouco as lembranças - um curso linear, como os rios ou as cronologias.
O "fio da memória", o fio condutor da narrativa no documentário, são as lembranças do Sr. Gabriel Joaquim dos Santos, nascido logo depois da abolição e falecido em 1985. Esse homem é excepcional em diversos sentidos: filho de escravos, construiu uma casa de acordo com seus "sonhos e pensamentos", alfabetizou-se, escreveu cadernos de assentamentos (uma denominação talvez um pouco mais aplicável 
a documentos oficiais do que a diários, como me parece ser o caso do Sr. Gabriel).

Mas não acredito que seja devido à sua excepcionalidade que ele tenha se tornado o sujeito/personagem/ narrador/condutor da memória que se pretende discutir no filme. Excepcional em suas práticas cotidianas, o Sr. Gabriel compartilhava de mecanismos da memória muito semelhantes aos das outras pessoas: suas reminiscências são fragmentárias e pouco hierárquicas, como são as lembranças de quase todas as pessoas.

Da chamada "história do Brasil", o Sr. Gabriel foi ao mesmo tempo aprendiz, narrador e sujeito. Foi aprendiz quando relatou que aqui havia portugueses e escravos, que D. Pedro deixou o Brasil para cá e Portugal para lá, que Washington Luís caiu, que as forças brasileiras foram lutar na $2^{\text {a }}$ Guerra Mundial. Foi narrador quando contou em seus registros pessoais a vida cotidiana de São Pedro da Aldeia; a mulher matou o marido num baile, o fulano se amasiou com beltrana... Foi sujeito quando contou sobre a greve na salina em que trabalhava, em 1946; sobre suas relações com os pais e a família; sobre seu amigo tornado irmão Guilherme e, acima de tudo, sobre a maneira como ele concebeu e realizou a Casa da Flor.

A forma de expor suas lembranças sobre os grandes fatos na periodização da história do Brasil e os mecanismos que ele usou para registrá-las trazem o Sr. Gabriel para o lado dos homens comuns. Os fatos se situam num plano longínquo, e com eles mantemos uma relação de conhecimento unilateral, sem interação possível. O Brasil foi colonizado, os negros foram escravizados, D. Pedro proclamou a independência e esse passado é imutável enquanto fato.

Mas o conteúdo das reminiscências pessoais do Sr. Gabriel o tornam um homem excepcional. De um lado, ele não estabeleceu nenhuma relação de hierarquia que torne o grito do Ipiranga mais importante do que a morte do marido no baile, nem a greve na salina têm menos espaço em seus diários do que a queda de um presidente - embora essa falta de hierarquia seja bastante comum em outros depoimentos ou narrativas de história de vida. A maior excepcionalidade está no suporte que ele inventou para imprimir suas memórias: para além dos diários anárquicos, a Casa da Flor é uma autêntica casa da memória, com sua arquitetura encantada e encantadora.

Como resistir à comparação dos que decoram a Casa da Flor com os fragmentos da memória? O Sr. Gabriel apanhou restos nos lixos, ganhou lâmpadas queimadas e recolheu coisas aparentemente sem serventia, posto que foram atiradas ao lixo, e reinventou os significados desses objetos. Ao fazê-lo, ele poderia estar se expressando de um modo sincrético: apropriarse de algo e dar-lhe novo significado, não é esse o mecanismo de produção do sincretismo?

Gosto de pensar que o Sr. Gabriel é herdeiro de uma tradição africana de reinvenção dos significados, ao mesmo tempo em que os materializa e os deixa como legado arquitetônico, ao construir um espaço físico que é também um santuário. Afinal, ele não tinha cozinha nem banheiro na sua Casa da Flor: ali, ele apenas dormia e sonhava o que iria materializar em seguida, ou seja, novas alegorias para a decoração da casa; ali comia a comida que sua sobrinha the trazia de fora, pronta; ali construiu seu altar, ali escreveu suas lembranças sobre uma pedra macia. Esse espaço físico era também um espaço ritual. O desejo de quem a construiu era impressionar: a casa foi feita de tal forma que quem a visse não a esqueceria.

Eduardo Coutinho encontrou nessa personagem a peça-chave para elaborar um ensaio sobre a condição do negro no Brasil da atualidade. Tendo por mote o centenário da abolição da escravidão, o cineasta gravou este documentário entremeando as memórias de Gabriel dos Santos com cenas do cotidiano da população negra, algumas vezes no espaço público, outras vezes relembrando suas histórias de vida. $\mathrm{O}$ roteiro, mesmo que não estivesse fechado antes do início da filmagem, sugere uma inspiração nas lembranças do Sr. Gabriel. 
Senão vejamos: os alunos negros de uma escola discutindo a abolição. Esses meninos e meninas desempenham o papel de aprendizes de um passado que não viveram mas do qual são herdeiros. A professora deixa isso claro: a Itália é importante para ela, pois ela nasceu lá... Com o atlas aberto, ela indaga ao aluno: a África representa o quê? Era a deixa para que o aluno respondesse que os negros, seus antepassados, vieram da África. O menino e seus colegas estão aprendendo isso, mas ao mesmo tempo trazem suas próprias percepções sobre o que foi a experiência da luta pela liberdade. Aquela mulher branca - a princesa, poderosa - assinou o papel, mas quem fez tudo foi a escrava Anastácia! Quem lutou foi Zumbi, o guerreiro, mas os negros não tinham força porque não tinham armas. Memória ou história?

Outras pessoas narram suas histórias pessoais e as ligam com a história institucional. Os membros da velha guarda da Mangueira, que ainda se lembram da repressão às rodas de samba e vêem as escolas de samba atuais como empresas; Aniceto do Império, que encontrou uma forma de superar o preconceito da loura que recuou quando o conheceu pessoalmente, depois de ser seduzida pela voz dele ao telefone; a senhora que protesta veementemente por ver coroada uma mulata como Rainha do Centenário da Abolição pela Confraria do Garoto, sendo que tem tanta negra bonita para ocupar aquele lugar...

O filme poderia ter optado por retratar a miséria em que vive boa parte da população negra no Brasil. Ele não deixa de fazer isso: há pessoas vivendo na rua, há meninos abandonados também morando nas ruas ou em instituições que os transformam em "Silvas" porque é impossível saber seus nomes quando eles são encontrados ainda bebês. No entanto, há um profundo respeito pela dignidade que todas essas pessoas ostentam, e a dignidade dá o tom quando se apresentam as condições em que negros de todas as idades vivem no Brasil cem anos depois da abolição. A senhora que se orgulha de sua voz de contralto, aptidão que lhe servia tanto para vender no tabuleiro quanto para cantar os hinos da igreja evangélica à qual ela se converteu; Maria, que vive em "comarcas" muito boas feitas de papelão e plástico nas ruas do centro do Rio de Janeiro.

Aniceto do Império, dentre todos os depoentes, ensina uma lição das mais proveitosas para nós, historiadores sempre às voltas com as questões da memória e especialmente aqueles que lidam com depoimentos orais. A princípio, ele se impressiona com as informações que o diretor do filme tem sobre sua pessoa, mas logo assume seu papel de centro daquela conversa: Aniceto classifica algumas das perguntas que lhe são dirigidas como "demasiadas" e chama seu interlocutor de "inocente" porque ele não sabe completar uma rima que um coro de partido alto certamente não deixaria passar em branco...

Ouvir o depoimento de Aniceto deixa claro para mim a profunda desigualdade que existe entre entrevistador e depoente. Essa desigualdade, por mais que seja calculada e por mais que o entrevistador se esforce em superar por meio das informações que ele coleta a respeito do depoente, será sempre um problema no relacionamento com o depoente, envolvendo racionalidade e emoção o tempo todo. Muitos de nós, senão todos, já viveram uma situação semelhante durante uma coleta de depoimento: por vezes somos tratados como inocentes (e quase sempre somos), por vezes somos envolvidos num turbilhão emocional difícil de romper (quais as vantagens de rompê-lo?), por vezes o depoente conta o que quer, sem travar uma interlocução com aquele que o entrevista, pois seu discurso não requer indagações. A memória está lá, elaborada, esperando o momento de encontrar expressão, sem que o roteiro que nós estabelecemos faça algum sentido para o depoente. Somos, na verdade, muito inocentes.

As personagens encontradas por Coutinho nos mostram a reinvenção da identidade, um processo que é individual e coletivo também, pensando no caso dos 
descendentes de africanos. A religião, as relações sociais e a família foram, entre outros, os elementos por meio dos quais os africanos de várias origens étnicas criaram uma nova identidade na América. Nos diversos lugares da África, eles certamente não se viam como "africanos" - essa categoria tão abstrata e imprecisa -, pois reconheciam as imensas diferenças culturais existentes entre eles. A possibilidade de se verem como negros, descendentes de africanos, foi criada no Brasil, nos confrontos durante o cativeiro e no pós-abolição, na luta contra o racismo. Ser negro, praticante do candomblé, membro de escola de samba, trabalhador informal, não são apenas heranças culturais africanas, são tradições criadas no cotidiano vivido no Brasil.

Por fim, gostaria de dizer que fiquei entusiasmado com a distinção que Eduardo Coutinho faz entre a "filmagem da verdade" e a "verdade da filmagem" - refiro-me ao seu depoimento no evento Ética e História Oral (COUTINHO, 1997). Decididamente, o diretor não foi inocente em optar pela segunda ao realizar seu trabalho. Ao lidar com um roteiro construído praticamente no ato da filmagem, Coutinho estava sujeito a situações imprevistas que acabaram sendo registradas e o espectador as percebe claramente no filme. Sua habilidade em lidar com o imprevisto é tão significa-

\section{Bibliografia}

COUTINHO, Eduardo. "O cinema documentário e a escuta sensível da alteridade". Projeto História (Ética e História Oral). tiva quanto a montagem daquilo que ele já conhecia, como as memórias escritas e edificadas do Sr. Gabriel dos Santos, e eu gostaria de reconhecer isso.

Ironicamente, o Sr. Gabriel morreu, foi enterrado e, mais tarde, seus ossos foram recolhidos e depositados em um saco plástico identificado apenas por um número - um número que não remete a nada, pois o administrador do cemitério admitiu que não se pode saber exatamente a quem pertenceram aqueles ossos em meio a tantos outros sacos plásticos... Nada mais significativo num filme que aborda a memória: para um homem que se preocupou tanto com o registro de suas reminiscências, não poderia haver um destino mais infeliz do que perder-se, misturar seus restos a uma massa sem identidade. Seus restos são irrecuperáveis, senão fisicamente, ao menos do ponto de vista do reconhecimento de sua importância como ser humano.

Sua Casa da Flor, se nada for feito, terá destino semelhante. Não seria o caso de tombá-la, preservála como lugar da memória? Afinal, se não estou sendo eu também muito inocente, a maneira como o $\mathrm{Sr}$. Gabriel concebeu a expressão de sua memória a partir dos restos, dos fragmentos, dos objetos quebrados e sem valor monetário, é a maneira como a maioria das pessoas a concebe, o que demonstraria o valor simbólico daquela casa.

São Paulo, Pós-Graduação em História da PUC/SP, n. 15, p. 165/191, abril de1997. 